\title{
Me engana que eu gosto! Falácias como mecanismo de produção do riso
}

\author{
You could've fooled me! Fallacies as laughing production mechanism
}

\author{
Ana Cristina Carmelino \\ Universidade Federal de São Paulo - UNIFESP - São Paulo - Brasil
}

Luiz Antonio Ferreira

Pontifícia Universidade Católica de São Paulo - PUC - São Paulo - Brasil

\begin{abstract}
Resumo: No processo de persuasão estão implicados diferentes tipos de argumentos. Há aqueles que parecem convincentes para grande parte do auditório, mas são falaciosos, produtos de raciocínios falsos, que apenas simulam a veracidade de um fato, acontecimento ou opinião. Conhecer os tipos de falácias é relevante para evitar armadilhas lógicas no processo argumentativo bem como para analisar a argumentação alheia. Este artigo pretende tratar desses argumentos a fim de desvelar outra função exercida por eles na arte de argumentar: a de produzir humor. Para isso, busca-se demonstrar como diferentes textos humorísticos se utilizam de falácias para provocar o riso. O corpus de análise consiste em exemplos retirados das edições impressas de 2015 da versão brasileira da revista $M A D$, um periódico de humor publicado no país desde 1974. O referencial teórico que fundamenta as análises advém da Retórica e da Lógica.
\end{abstract}

Palavras-chave: Falácia. Argumentação. Humor. MAD.

Abstract: In the persuasion process they are involved different types of arguments. There are those who seem convincing for the most part of the audience, but are fallacious, false reasoning products, which only simulate the truth of a fact, event or opinion. Knowing types of fallacies is relevant to avoid traps in the logical argumentative process and to analyze other people's arguments. This article aims to address these arguments in order to reveal another function performed by them in the art of reasoning: to produce humor. For this, we seek to demonstrate how different humorous texts are used fallacies to provoke laughter. The analysis corpus consists of examples taken from the printed editions in 2015 of Brazilian version of MAD magazine, a journal of humor published in the country since 1974. The theoretical framework underlying the analysis comes from the Rhetoric and Logic.

Keywords: Fallacy. Argumentation. Humor. MAD. 


\section{Introdução}

"Ela estava se metendo a besta com aquele vestido verde e brilhante. Por certo, emprestou da amiga dela ou comprou em algum brechó barato!"1. Alguém menos avisado pode deixar-se levar por construções desse tipo e dissociar a passionalidade do enunciado do acontecimento relatado: "ela estava vestida de verde". As falácias são assim: remetem o auditório para uma zona fronteiriça entre o lógico e o linguístico por meio de artifícios retóricos que podem ter validade emocional, íntima, psicológica, mas, quando submetidos à análise da correta estruturação dos raciocínios, não se sustentam como argumentos válidos logicamente, pois, do ponto de vista lógico, destacam apenas duas maneiras de errar: erra-se por racionar "mal com dados corretos" ou por raciocinar "bem com dados falsos" (GARCIA, 2002, p. 316). No primeiro caso, está-se diante de um erro que resulta de um vício de forma; no segundo, de matéria (fatos). Por isso, o "por certo" do exemplo acima é, de algum modo, armadilha persuasiva para conduzir o auditório a uma conclusão falsa.

Como somos seres retóricos, vemo-nos constantemente imersos em situações que pretendem estabelecer acordos entre o que pensamos e o que desejamos que os outros pensem e, para isso, conduzimos o processo de argumentação por meio de diferentes construções e conduções de raciocínio. No exemplo mencionado, é nítida a intenção do orador: valer-se de um argumento logicamente inconsistente, sem fundamento, inválido ou falho com o objetivo de provar como verdadeiro o que é apenas uma conclusão pautada na inferência. Quando, como ouvintes ou leitores, conhecemos o ethos do orador, podemos atentar menos ou mais para a intencionalidade do que é dito e, assim, buscar entender se estamos diante da ingenuidade do argumento e compreendermos que estamos diante de um paralogismo (falácias cometidas involuntariamente) ou de um sofisma (raciocínio ardiloso, propositalmente falacioso).

\footnotetext{
${ }^{1}$ Exemplo criado pelos autores deste artigo.
}

De modo amplo, o termo "falácia", proveniente etimologicamente do latim fallacia, significa "erro", "engano", "trapaça", "mentira", "inverdade", "falsidade", "astúcia". Logo, pode-se dizer que é "falaz" tudo aquilo que engana, induz ao erro ou ilude. Nesse sentido, alguns discursos são elaborados por meio de recursos ardilosos, em função do propósito comunicativo. Se, por exemplo, o objetivo é provocar o riso, as falácias podem funcionar como ótimo expediente retórico.

Partindo dessas considerações, este artigo explora a utilização da falácia como "gatilho" para que, no absurdo lógico, provoque situações humorísticas capazes de levar o auditório ao riso. $\mathrm{Na}$ verdade, defendemos a tese de que as falácias podem constituir uma técnica de produção de humor. Tema ainda não abordado cientificamente. O recorte do corpus de análise são textos das edições impressas de 2015 da revista MAD. Publicado no Brasil desde 1974 e destinado ao público jovem e adulto, esse periódico de humor brinca com (e critica) aspectos da cultura popular buscando mover os leitores (seu auditório) à ação: rir e refletir. Os pressupostos teóricos que fundamentam as análises aqui empreendidas advêm da Lógica e da Retórica.

\section{Da complexidade do conceito de falácia}

O conceito de falácia é pensado sob diversas perspectivas teóricas. Logo, uma das causas da complexidade que se instaurou sobre sua classificação certamente está relacionada às diferentes abordagens que a tomam como objeto de estudo. A literatura sobre o assunto destaca três delas, todas vinculadas de certa forma à argumentação: a Lógica, a Dialética e a Retórica. Santibáñez Yáñez e Marafioti (2008, p. 9) refletem sobre os porquês da complexidade do assunto:

Falacia es un término esquivo, pero vital. Esquivo porque no hay unanimidad em su definición, en lós criterios para distinguir su funcionamiento y evaluación, tampoco en las especies que abarca, esto es, en una clasificación taxativa e sus posibles tipos. Vital porque, en las esferas de dominio de lo cotiano, los hablantes acusan recibo de ciertos movimientos dialógicos considerados injustos porque, por ejemplo, evitan el peso de 
la prueba, caen en descalificaciones personales o simplesmente los someten a irritantes autoalabanzas que, sin justificación, su interlocutor emplea como herramienta para enfatizar sus - a veces inexistentes virtudes $^{2}$.

De acordo com Reñón (2013), o ponto de vista lógico estaria representado pela metáfora da construção de argumentos e noções associadas ("solidez", "fundamentación"); o dialético, pela visão da argumentação como um combate, com suas armas, vicissitudes e leis de guerra; o retórico, por sua vez, pela imagem da apresentação ou representação de um caso em um cenário diante de um auditório.

A Lógica, que parte do enfoque lógicoepistemológico, considera os argumentos como produtos textuais (tramas semânticas) que se estruturam basicamente por premissas $(P)$ e conclusão (C) com um nexo inferencial (premissa nexo inferencial - conclusão). Por adotar como paradigma argumentativo a demonstração ou a prova conclusiva, determina a validade e a força dos argumentos por critérios lógicos e metodológicos. Nesse contexto, a falácia consiste em uma prova falsa ou fraudulenta. Segundo Reñón (2013, p. 109):

una falacia viene a ser sustancialmente uma prueba o un intento de justificación epistémica fallidos por seguir un procedimiento viciado, de modo que se trata de un error o un fallo relativamente sistemático $\mathrm{y}$, por lo regular, encubierto o dissimulado al ampararse em recursos retóricos o emotivos para compensar la carencia o la insuficiencia de medios de persuasión racional ${ }^{3}$.

\footnotetext{
${ }^{2}$ Falácia é um termo evasivo, mas vital. Evasivo porque não existe uma unanimidade em sua definição, nos critérios para distinguir o seu funcionamento e avaliação, tampouco nas espécies que abarca, isto é, em uma classificação taxativa e seus possíveis tipos. Vital porque, nas esferas de domínio cotidianas, os falantes acusam o recebimento de certos movimentos dialógicos considerados injustos, porque, por exemplo, evitam o peso da prova, caem nas desqualificações pessoais ou simplesmente os submetem a irritantes autoelogios, sem justificação, seu interlocutor emprega como ferramenta para enfatizar suas - por vezes inexistentes virtudes. (SANTIBÁÑEZ YÁÑEZ; MARAFIOTI. 2008, p. 9).

${ }^{3}$ uma falácia vem a ser substancialmente uma prova ou uma tentativa de justificação epistêmica frustrada por seguir um procedimento viciado, de modo que se trata de um erro ou uma falha relativamente sistemática e, geralmente, oculto ou dissimulado ao se amparar em recursos retóricos ou emotivos para compensar a carência ou a insuficiência de meios de persuasão racional (REÑóN, 2013, p. 109).
}

De acordo com Copi (2014), para a Lógica, é costume reservar 0 nome "falácia" àqueles argumentos ou raciocínios que, embora incorretos, podem ser psicologicamente persuasivos, daí considerar o termo como uma forma de raciocínio que parece correta, mas que, quando examinada cuidadosamente não o é.

O enfoque da Dialética volta-se para a interação discursiva e dinâmica entre agentes que desempenham papéis opostos e complementares ao longo de um debate: o de proponente ou defensor de uma posição e o de oponente ou adversário. Nesse sentido, o paradigma ou modelo argumentativo é a discussão racional (crítica), cujo propósito principal é determinar as ações corretas ou incorretas de interação ou de confronto entre os papéis argumentativos com o objetivo de resolver de forma racional uma diferença de opinião. Sob esse ponto de vista, a falácia consiste na violação do código, como bem registra Reñón (2013, p. 111):

será falaz a intervención argumentativa que, en el contexto de la discusión, atente contra las condiciones o las reglas que gobiernan el buen curso y el buen fin cooperativo de la discusión, de modo que, por ejemplo, no respete las máximas conversacionales que presiden el entendimiento mutuo y la fluidez de la comunicación, o viole alguna de las reglas del código de la discusión crítica ${ }^{4}$.

A perspectiva Retórica centra-se nos processos de comunicação e de influência interpessoal com fins de persuadir. Partindo do paradigma do discurso convincente, busca tratar dos recursos efetivos e estratégias eficazes para induzir a crenças, ações e disposições. A falácia, nesse caso, é compreendida como uma distorção da interação, um modo de manipulação.

Ainda à luz dos pressupostos retóricos, conforme assinala Reñón (2013), são levados em conta certos parâmetros (aspectos pragmáticos e contextuais) não considerados pela Lógica e

\footnotetext{
${ }^{4}$ será falaciosa a intervenção argumentativa que, no contexto da discussão, violar as condições ou regras que regem o bom andamento e o bom fim cooperativo da discussão, de modo que, por exemplo, não respeite as máximas conversacionais que regem a compreensão mútua e fluidez da comunicação, ou viole alguma das regras do código da discussão crítica (REÑóN, 2013, p. 111).
} 
Dialética. É o caso de: ethos (agente indutor), caráter ("el talante") e personalidade do argumentador ou do orador, sua imagem, seu encanto e sua atuação; pathos (receptor), a disposição receptiva dos interlocutores ou do auditório; kairós (situação argumentativa), a oportunidade de uma intervenção no âmbito da situação, ou seja, no momento do discurso.

Esses três parâmetros (ethos, pathos e kairós) determinam noções importantes com relação às falácias, segundo Reñón (2013). Do orador, conta a intenção persuasiva. Essa intenção pode ser reta e ingênua quando o próprio argumentador recorre a um paralogismo que, involuntariamente, transmite ao auditório, ou seja, não há intenção de enganar. Se a intenção se supõe falaz, então será dolosa e fraudulenta. Nesse caso, o orador consciente e intencionalmente emprega um recurso capcioso para induzir o auditório a aceitar uma decisão ou crença ou ainda para confundi-lo numa discussão. Trata-se da produção de sofismas: raciocínio elaborado com a intenção de enganar, produzido de má-fé (cf. LIARD, 1973; GARCIA, 2002; COPI, 2014).

Liard (1973) ressalta que para alguns estudiosos, o paralogismo é um tipo de sofisma. Para outros não, pois não é produzido de má-fé, isto é, não é intencionalmente elaborado para enganar. Segundo Aristóteles, porém, qualquer falso silogismo era considerado um paralogismo, pois contém obrigatoriamente uma premissa ambígua.

Por parte do auditório, o que conta é sua cumplicidade com o erro, com a confusão ou o engano induzidos, independentemente de saber se tem mais ou menos consciência de ser enganado ou de participar de uma confusão. Nesse sentido, "cabría distinguir entre un intento falaz, la 'metira' propuesta o el engaño pretendido por el inductor, y uma falácia efectiva, la cumplida com la anuência del receptor engañado"” (REÑóN, 2013, p. 115).

Um discurso não será completamente falaz se não produzir os seus efeitos deletérios sobre a

\footnotetext{
5 caberia distinguir entre uma intenção falaz, uma mentira ou engano proposital, pretendido pelo indutor, e uma falácia eficaz, a realizada com o consentimento do receptor enganado (REÑÓN, 2013, p. 115).
}

compreensão, a vontade ou os sentimentos do destinatário. Isso coloca em xeque a competência discursiva do auditório e o contexto de uso concreto da falácia: haverá falácias que não funcionam para certas pessoas em certos contextos, no entanto, por outro lado, estas mesmas falácias poderão ser eficazes para outras pessoas em outros contextos.

É importante ressaltar, conforme Reñón (2013), que apenas são falácias propriamente ditas aquelas eficazes, pois alcançam o propósito do orador de persuadir, enganar ou confundir. Se assim é, essa perspectiva de validade da falácia enfatiza a cooperação do receptor para o sucesso do estabelecimento de acordos entre orador e auditório.

Com base nos registros de Reñón (2013), podemos resumir as propostas das perspectivas teóricas no Quadro 1:

Quadro 1 - Resumo das abordagens teóricas que tratam de falácia, adaptado de Reñón (2013, p. 107)

\begin{tabular}{|c|c|}
\hline LÓGICA & $\begin{array}{l}\text { - argumentos textuais (produto) } \\
\text { - paradigma: prova conclusiva } \\
\text { - noção de falácia: prova falsa, } \\
\text { enganosa, fraudulenta } \\
\text { - imagem: argumento como } \\
\text { edifício }\end{array}$ \\
\hline DIALÉTICA & $\begin{array}{l}\text { - argumentação interativa e } \\
\text { dinâmica (procedimento) } \\
\text { - paradigma: discussão racional } \\
\text { - noção de falácia: violação das } \\
\text { regras (do código) } \\
\text { - imagem: argumentação como } \\
\text { combate, forma de confrontação }\end{array}$ \\
\hline RETÓRICA & $\begin{array}{l}\text { - processo de comunicação e } \\
\text { influência interpessoal com o } \\
\text { propósito de persuadir } \\
\text { - paradigma: } \\
\text { convincente } \\
\text { - noção de falácia: distorção da } \\
\text { interação, manipulação } \\
\text { - imagem: representação num } \\
\text { cenário com a presumida } \\
\text { cumplicidade ou implicação do } \\
\text { auditório }\end{array}$ \\
\hline
\end{tabular}

No que concerne à classificação das falácias, a tradição lógica e filosófica procurou inventariar e batizar falácias típicas. Há uma vasta lista, que, como afirmamos, não é universalmente aceita. Copi (2014), a título de ilustração, divide as falácias em formais e não formais, mas trata especificamente das não formais. Dentre estas estão as que o estudioso 
categoriza como falácias de relevância e falácias de ambiguidade. Para esse mesmo autor, que faz um levantamento de estudiosos que tratam desses argumentos, a variação é grande.

Diante do exposto, como um norte para identificar as falácias comuns nos textos da revista $M A D$, adota-se aqui o Guia de falácias proposto por Stephen Downes (s.d.), tendo em vista ser um dos materiais sobre o assunto mais citados e elaborado com base em diferentes textos da Lógica e raciocínio crítico. A fim de tornar didática a classificação das falácias, apresentamos todos os tipos propostos por Downes de forma sintetizada no Quadro 2.

Quadro 2 - Tipos de falácias propostas por Stephen Downes (s.d.)

\begin{tabular}{|c|c|}
\hline CATEGORIAS & TIPOS \\
\hline $\begin{array}{l}\text { FALÁCIAS DA } \\
\text { DISPERSÃO }\end{array}$ & $\begin{array}{l}\text { Falso dilema } \\
\text { Apelo à ignorância (argumentum } \\
\text { ad ignorantiam) /Derrapagem } \\
\text { (bola de neve) /Pergunta } \\
\text { complexa /Apelo a motivos (em } \\
\text { vez de razões) /Apelo à força } \\
\text { (argumentum ad baculum) } \\
\text { Apelo à Piedade (argumentum } \\
\text { ad misercordiam) /Apelo às } \\
\text { consequências (argumentum ad } \\
\text { consequentiam) /Apelo a } \\
\text { preconceitos / Apelo ao povo } \\
\text { (argumentum ad populum) } \\
\text { Fugir ao assunto } \\
\text { Ataques pessoais (argumentum } \\
\text { ad hominem) /Apelo à autoridade } \\
\text { (argumentum ad verecundiam) } \\
\text { Autoridade anônima } \\
\text { Estilo sem substância }\end{array}$ \\
\hline $\begin{array}{l}\text { FALÁCIAS } \\
\text { INDUTIVAS }\end{array}$ & $\begin{array}{l}\text { Generalização precipitada } \\
\text { Amostra limitada } \\
\text { Falsa analogia } \\
\text { Indução preguiçosa } \\
\text { Omissão de dados }\end{array}$ \\
\hline $\begin{array}{l}\text { FALÁCIAS COM } \\
\text { REGRAS GERAIS }\end{array}$ & $\begin{array}{l}\text { Falácia do acidente } \\
\text { Falácia inversa do acidente }\end{array}$ \\
\hline FALÁCIAS CAUSAIS & $\begin{array}{l}\text { Depois disso, por causa disso } \\
\text { (post hoc ergo propter hoc) } \\
\text { Efeito conjunto/Falsa causa } \\
\text { Causa genuína, mas } \\
\text { insignificante (causa diminuta) } \\
\text { Tomar o efeito pela causa } \\
\text { Causa complexa }\end{array}$ \\
\hline FALHAR O ALVO & $\begin{array}{l}\text { Petição de Princípio (petitio } \\
\text { principii)/Conclusão Irrelevante } \\
\text { (ignoratio elenchi)/Espantalho }\end{array}$ \\
\hline $\begin{array}{l}\text { FALÁCIAS DA } \\
\text { AMBIGÜIDADE }\end{array}$ & $\begin{array}{l}\text { Equívoco } \\
\text { Anfibologia } \\
\text { Ênfase }\end{array}$ \\
\hline
\end{tabular}

\begin{tabular}{|c|c|}
\hline ERROS CATEGORIAIS & $\begin{array}{l}\text { Falácia da composição } \\
\text { Falácia da divisão } \\
\text { Non-sequitur (não se segue que) } \\
\text { Falácia da afirmação da } \\
\text { consequente } \\
\text { Falácia da negação da } \\
\text { antecedente } \\
\text { Falácia da inconsistência }\end{array}$ \\
\hline FALÁCIAS CAUSAIS & $\begin{array}{l}\text { Depois disso, por causa disso } \\
\text { (post hoc ergo propter hoc) } \\
\text { Efeito conjunto/Falsa causa } \\
\text { Causa genuína, mas } \\
\text { insignificante (causa diminuta) } \\
\text { Tomar o efeito pela causa } \\
\text { Causa complexa }\end{array}$ \\
\hline FALHAR O ALVO & $\begin{array}{l}\text { Petição de Princípio (petitio } \\
\text { principii)/Conclusão Irrelevante } \\
\text { (ignoratio elenchi)/Espantalho }\end{array}$ \\
\hline $\begin{array}{l}\text { FALÁCIAS DA } \\
\text { AMBIGÜIDADE }\end{array}$ & $\begin{array}{l}\text { Equívoco } \\
\text { Anfibologia } \\
\text { Ênfase }\end{array}$ \\
\hline ERROS CATEGORIAIS & $\begin{array}{l}\text { Falácia da composição } \\
\text { Falácia da divisão } \\
\text { Non-sequitur (não se segue que) } \\
\text { Falácia da afirmação da } \\
\text { consequente } \\
\text { Falácia da negação da } \\
\text { antecedente } \\
\text { Falácia da inconsistência }\end{array}$ \\
\hline
\end{tabular}

\section{As falácias como gatilho do riso nos textos da $M A D$}

Os textos ou discursos humorísticos - que fazem parte do campo do humor, segundo defendem Possenti (2010) e Carmelino e Gatti (2017) - podem circular em diferentes lugares e abordar temas diversos. Há, porém, um dado comum entre eles: a produção do elemento cômico que os caracteriza depende sempre de uma técnica, seja ela de ordem linguística ou não.

A $M A D$, revista de/com quadrinhos, foi lançada nos Estados Unidos em 1952 pelo empresário Bill Gaines e pelo editor e cartunista Harvey Kurtzman e possui, reconhecidamente, intencionalidade humorística, eivada de ácida crítica aos aspectos da cultura popular americana. Por sua capacidade de universalização do humor e contundência crítica às mazelas sociais, foi e é traduzida em diversas línguas.

No Brasil, a $M A D$ começou a ser impressa em julho de 1974 pela editora Vecchi (que a publicou até 
1983). Nos anos e décadas seguintes, o título migrou para outras empresas - Record (1984-2000), Mythos (2000-2006) e Panini (2008 até o presente) -, que mantiveram a linha editorial estabelecida desde 0 início da veiculação, a de mesclar conteúdo estrangeiro com nacional.

Ainda que considerada uma revista de/com quadrinhos, a $M A D$ apresenta em sua constituição uma diversidade de gêneros/textos. Ou seja, além dos conhecidos gêneros dos quadrinhos (como tira, charge, cartum e histórias em quadrinhos), há muitos outros, caso de editorial, carta de leitor, entrevista, crônica, provérbio, frase, resumo, resenha, slogan, dica, anúncio etc. (CARMELINO, 2012, 2014). Essas informações são relevantes na medida em que é possível encontrar a presença de falácias em diferentes gêneros/textos do periódico.

Classificado pelos editores como um "humor via veia jugular" ("humor in a jugular vein" - nomeado na lombada dos primeiros exemplares da revista), o lema proposto por Gaines quando da criação da revista era: "Não leve nada a sério demais". Nesse sentido, a publicação não considera qualquer assunto como sagrado ou tabuístico.

Os autores da MAD ressaltam, por isso, categorias bem nítidas de constituição do humor que, grosso modo, podem ser resumidas em uma: corrosiva, por acentuar o tosco dos fatos sociais de modo agressivo, irreverente, subversivo e, de modo geral, inteligente. Para bem concretizar seus intentos de irreverência e visão sarcástica dos fatos do mundo, os colaboradores/autores desse periódico lançam mão de diferentes recursos (de ordem linguística ou não) para suscitar o riso do auditório a que se dirige.

Nas palavras de Carmelino (2012, 2014), que analisa a versão brasileira da revista, as técnicas mais recorrentes de produção de humor são: conhecimento prévio, inferência, exagero, ironia, jogo de palavras (trocadilho), estereótipo, variação linguística (linguagem repleta de gírias, ultracoloquial, livre de normas e sem pudor algum) e autodepreciação. Neste texto, defendemos a presença de outro mecanismo, o uso intencional de falácias.

No plano da constituição dos raciocínios, as falácias são muito comuns e ardilosamente construídas: os oradores da $M A D$ fazem uso de sofismas, propagam falsos axiomas, simulam ignorância de uma questão, dirigem o auditório para observações inexatas, criam falsas causas, estabelecem analogias disparatadas com um objetivo único: gerar riso. A estratégia retórica é sofisticada, uma vez que, num simulacro bem urdido linguisticamente, demonstram que estão sofismando, mas, no interior do texto, a aparência é de uma falácia, como ocorre nos exemplos a seguir:

(1) "Os debates entre candidatos a presidente e entre os próprios eleitores foram tão acalorados em 2014 que é bem possível que a água do sistema tenha evaporado por causa disso." (FREITAS, 2015, p. 35).

O enunciado em questão faz parte do texto "10 motivos mais prováveis para a falta d'água em São Paulo", que consta da edição de fevereiro de 2015 da MAD. Nele, Freitas resgata dois assuntos bastante noticiados no Brasil em 2014: a eleição à presidência do país, ocorrida em outubro; e a queda nos níveis de água do Sistema Cantareira, em São Paulo.

No caso, a relação entre a premissa ("os debates entre candidatos a presidente e entre os próprios eleitores foram acalorados") e a conclusão ("que é bem possível que a água do sistema tenha evaporado por causa disso") configura uma falácia causal, do tipo propter hoc. Evidentemente, o autor vale-se, no interior da premissa inicial, do sentido conotativo do termo "acalorados" (repletos de paixão, entusiasmados) e conclui o raciocínio a partir do valor denotativo do mesmo termo (alta intensidade de calor, sob sol forte) para justificar a evaporação da água do sistema.

Como se percebe, o artifício lexical ("acalorados") reflete-se no plano semântico, que é intensificado pelo uso do advérbio "tão" para ampliar a ideia de intensidade do calor a ponto de causar 
evaporação. Para aparentemente simular uma "possibilidade", o autor se utiliza da expressão "é bem possível", ainda que saiba, nessa falácia da explicação, feita pela distorção nítida dos fatos, que, jocosamente, sumule o raciocínio comum ao método experimental (observação, hipótese, verificação e generalização), uma vez que o autor pretende estabelecer uma relação de causa-efeito por meio da observação de fatos sucessivos.

(2) "A gente preparou um presunto bacana no último feriado de Natal, e acho que rolou um lance bacana entre nós. - Tudo bem se eu ligar só para bater um papo, né?" (MAIKO; MECOUCH, 2015, p. 40)

Por volta de 2006, a MAD americana publicou um artigo intitulado "Perguntas que gostaríamos de fazer para a linha direta do peru", que se referia a um serviço telefônico para donas de casa desocupadas dos Estados Unidos que não saiam de casa e tinham dúvidas sobre qualquer assunto. Com base nesse artigo, a edição de março de 2015 da MAD brasileira resolveu "encher linguiça" (como os próprios autores explicitam) e fazer as suas próprias perguntas "à linha direta do peru".

O excerto acima é um exemplo das questões feitas. Como se verifica, ele externa um diálogo assimétrico (cf. MARCUSCHI, 1986) em que um dos interlocutores inicia, orienta, dirige e conclui a interação por meio de pressão sobre o auditório. 0 humor, aqui, é produzido por meio da exploração de uma falácia comum, denominada "erro do acidente", ao tomar um evento acidental como atributo essencial para uma generalização falsa: como nos demos bem no Natal, conquisto o direito de ligar quando quiser.

De modo estrito, os autores fazem um apelo à consequência (argumentum ad consequentiam) ao considerarem a primeira premissa como verdadeira ("A gente preparou um presunto bacana no último feriado de Natal, e acho que rolou um lance bacana entre nós"), conforme a consequência desejada (“Tudo bem se eu ligar só para bater um papo, né?"); a premissa é tida como válida somente porque a conclusão agrada os oradores. A falácia, aqui, não reside no uso do léxico como gatilho para provocar o humor, mas, sim, na estruturação material do argumento, por meio de um proposital engano na apreciação dos fatos: exprimir duas ideias totalmente independentes e transpor essa ideia a uma totalidade não pertinente.

(3) "O ano era 1888. E tava tudo certo pro grande show do tataravô do MC Brinquedo, menos uma coisa, o mesmo era escravo e não poderia estar presente na festa pois não poderia sair da senzala naquela noite. Solução: a novinha Izabel, mediu suas atitudes, e assinou a lei Áurea, liberando o galerão pra curtir o pancadão" (BRUM, 2015, p. 21)

(4) "Anos mais tarde, depois de vir morar no Brasil, D. Pedro I é desafiado pelo seu amigo Chalaça Brinquedo a medir suas atitudes e, na humildade do bagulho, tornar o Brasil independente, pra que a música nacional não fosse o fado português e sim o funk nacional." (BRUM, 2015, p. 21)

Os fragmentos (3) e (4) constam do texto "Meça suas palavras na história", da edição de junho de 2015 da $M A D$. Já nas primeiras linhas, o exemplo (3) assume um tom caracteristicamente narrativo, próximo do relatar histórico de um fato. É justamente a incongruência histórica que explicita 0 tom humorístico da narrativa: união do funk contemporâneo (pela menção a "MC Brinquedo", um cantor brasileiro do estilo "funk ousadia") com a escravidão do século XIX. Reside aí o indício claro de que o restante do texto se formará por meio de um paralogismo: os fatos serão escamoteados para falsear a conclusão.

O autor simula a falácia da observação inexata para imprimir humor ao episódio histórico da libertação dos escravos pela Princesa Isabel, ocorrido em 13 de maio de 1888. O termo "solução" reforça a ideia de uma falácia causal "por causa disso" (propter hoc), mas se trata de evidente simulação da 
ignorância da causa que provocou o ato histórico. Reforça, ainda, o gatilho humorístico a utilização de falácia indutiva do tipo "generalização precipitada" (uma amostra limitada que tende a apoiar uma conclusão tendenciosa) e "omissão de dados" (quando são excluídos dados importantes para a conclusão).

No excerto (4), todo o humor do trecho se concentra na exploração da memória discursiva do leitor e na utilização da falácia da falsa causa, que consiste em afirmar que, apenas porque dois eventos ocorreram no mesmo espaço de tempo, eles estão necessariamente relacionados. Em resumo, uma falácia mais ampla e significativa se impõe: a da explicação pela distorção de fatos que, amplamente conhecidos e reconhecidamente subvertidos, provocam riso fácil no auditório com conhecimento prévio. No caso, sabemos que, na história do Brasil, D. Pedro I não foi desafiado a medir suas atitudes por um amigo chamado "Chalaça Brinquedo" nem que a música nacional (a que se diz substituir o fado português") seja apenas o funk.

(5) "99\% dos usuários do Facebook postaram alguma coisa na última semana que os torna inaptos para empregos públicos. (Tim adicionou três fotos ao álbum "Bebendo sozinho)" (SANTOPADRE; WAITE, 2015, p. 29)

O texto "Fatos sobre o Facebook", do qual faz parte o exemplo acima, busca mostrar que a rede social conhecida como Facebook sabe tudo sobre as pessoas, mas o inverso não é verdadeiro: as pessoas não sabem tudo sobre o Facebook. Desse modo, nesse fragmento, os autores se utilizam de um argumento conhecido como ad hominem, que consiste em atacar o caráter ou traços pessoais do oponente.

Logo, o humor nasce da falácia indutiva denominada falsa analogia, da generalização precipitada, mas explicitada como se fosse uma verdade irrefutável. A afirmação gratuita, revestida de um elemento fortemente persuasivo como o lugar da quantidade (99\%) esconde/mostra a relação entre o fato declarado e o que se considera como sua causa.

(6) "Todos os pagamentos são definitivos e não há devoluções. Sim, mesmo que você descubra que tem um parentesco com Hiltler" (KEIL, 2015, p. 8)

(7) "Nos reservamos o direito de compartilhar suas informações pessoais com a NSA. Mas dado que $99 \%$ das suas "informações" são vídeos com gatinhos e selfies no banheiro, pode ficar tranquilo" (KEIL, 2015, p. 8)

Epiquerema é um tipo de silogismo, muito comum na vida cotidiana, que consiste em ter premissas seguidas de provas, de natureza causal ou explicativa. Esse é o princípio utilizado por $M A D$ nos fragmentos acima para ressaltar a falácia da causa diminuta ou pouco importante (também conhecida como genuína, mas insignificante) e para produzir o tom humorístico.

Nos enunciados (12) e (13), que fazem parte do texto "Termos e condições que podem ter passado batido por você", da edição de junho de 2015 da $M A D$, o clássico recurso do raciocínio indutivo é aproveitado pelo autor para tornar ainda mais absurda a conclusão, pois vai do particular para o particular com aparente intenção de criar uma relação efeito $x$ causa com aspecto de verdade geral. Notese 0 tom apodítico presente nas duas premissas iniciais: "Todos os pagamentos são definitivos e não há devoluções" e "Nos reservamos o direito de compartilhar suas informações pessoais com a NSA".

Projeta-se, então, a imagem autoritária do orador e o auditório, em posição inferiorizada no discurso, "deve" acatar o que se delibera como correto e justo. Pretende-se assim fazer parecer racional o que é apenas afetivo e sustentado pela hierarquia de valores do auditório. O aspecto de diálogo imprime aos enunciados ainda mais proximidade: "pode ficar tranquilo" ou "mesmo que você descubra" e, desse modo, simula um auditório 
particular quando, na verdade, a revista atinge um auditório universal.

(8) "De lá pra cá, o país passou por golpe militar, ditadura, eleições diretas até a chegada do povo ao poder. Porém, como ninguém escuta um moleque de 13 anos, eleitor nenhum mede suas atitudes na hora de escolher governantes, e fica de "roça roça" com as urnas, deixando a história do nosso país cada vez mais zoada" (BRUM, 2015, p. 2)

Como afirma Bergson (2007), para compreender o riso é preciso recolocá-lo em seu meio natural e reconhecer sua função e significação sociais. No trecho acima, Brum faz uma reconstituição histórica dos acontecimentos políticos no Brasil nas décadas de setenta até nossos dias por meio de uma premissa válida e verificável. A seguir, introduz o termo "porém" e levanta críticas ao comportamento popular em períodos de eleição.

O gatilho para o riso reside justamente na amplitude falaciosa da conclusão pelo recurso da falácia indutiva: generalização precipitada, amostra limitada, falsa analogia e omissão de dados. De todo modo, por meio desse artifício, o autor não deixa de ressaltar, de forma engraçada, a irresponsabilidade do auditório em relação aos destinos do país e, assim, calca-se no humor para dar ao riso uma função social significativa.

(9) "Assistir à TV aos domingos. Os programas de auditório do domingo fazem você chorar? Não desperdice essa água toda, meu irmão!" (OLIVEIRA; MARTINS, 2015, p. 27)

O país viveu uma crise hídrica muito séria nos últimos anos. O enunciado (9), um dos vários que compõe o texto "Dicas MAD para tomar banho em tempos de falta d'água", considera o momento trágico na vida dos brasileiros e busca a incongruência da conclusão para destacá-lo humoristicamente. Tratase de um recurso falacioso denominado non sequitur (não se segue que), um tipo de falácia no qual a conclusão não se sustenta nas premissas. Há uma violação da coerência textual; a forma de argumento é inválida, inconsistente.

Em outro plano, no social, a criação do enunciado pretende provocar o riso como espécie de alívio para a liberação de uma energia nervosa muito natural em momentos históricos de perturbação da ordem social. Embora ironize a situação catastrófica, o autor vale-se do risível com um propósito social e move, de algum modo, conforme assinala Ferreira (2014), o sujeito pragmático (movido pelo fazer: é preciso economizar água), o sujeito cognitivo (movido pelo saber: a crise é séria e compromete a vida em sociedade) e o sujeito passional (movido pelo sentir).

Figura - Arte e texto de Wesley Sampaio, Sessão Tapinha não dói

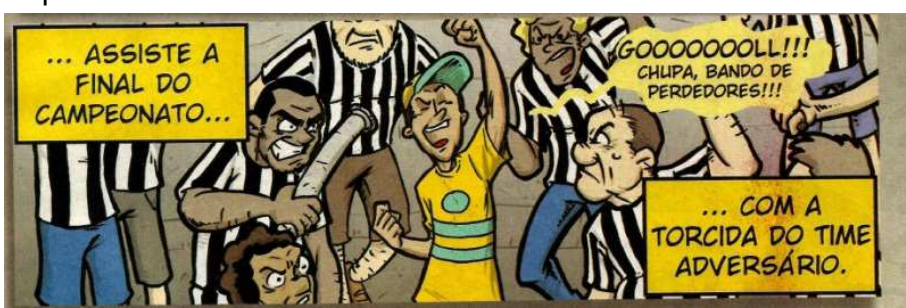

Fonte - MAD, São Paulo, Panini, n. 80, p. 39, mar. 2014.

O fragmento acima, uma cena de uma história em quadrinhos maior, consiste em uma das respostas que completam o título do texto "Você sabe que gosta de apanhar quando...". Logo, assistir "a final do campeonato... com a torcida do time contrário" seria uma forma de gostar de apanhar. No texto como um todo, o autor brinca com o fato de algumas pessoas "acharem graça em levarem uns sopapos".

O humor deflagrado reside justamente na falácia da inconsistência, pela construção de um raciocínio com premissas contraditórias, com explícito propósito de incitar as paixões no auditório. A incongruência da situação é gatilho para o riso, pois desperta a reação imediata a algo inesperado e não lógico: sabe-se que ninguém gosta de apanhar, sabese também que não é comum pessoas que torcem para um time assistirem a um jogo na torcida adversária. O autor evidencia, então, um momento de transgressão da ordem estabelecida na memória social para ampliar a comicidade. 
(10) "O Facebook, sozinho, fez com que desejar "Feliz Aniversário" para alguém se tornasse algo totalmente corriqueiro" (SANTOPADRE; WAITE, 2015, p. 29)

O fragmento (11) também faz parte do texto "Fatos sobre o Facebook". Pautando-se na força das mídias sociais, o autor não fundamenta nem justifica convenientemente a premissa inicial e considera como fato demonstrado aquilo que deveria demonstrar. Como a premissa é utilizada para provocar riso, a invenção criativa de fatos assume características de verdade.

$\mathrm{Na}$ realidade, porém, o autor apenas conjectura sobre uma situação provável ao apresentar informações imprecisas sobre um o fenômeno que pode ou não ter ocorrido e sobre o qual não se pode absolutamente generalizar. A figura do exagero, nesse caso, também faz parte da produção do humor. O uso do termo "sozinho", em "O Facebook, sozinho, fez com que...", torna a construção por si só hiperbólica.

(11) "Enquanto você lia este artigo, o Facebook tinha acabado de vender os seus dados pessoais para uma empresa estrangeira que fabrica panos de pratos não inflamáveis" (SANTOPADRE; WAITE, 2015, p. 29)

(12) "O sinal do celular é o melhor de toda a galáxia quando você passa a 10 metros do satélite da Globastar" (KEIL, 2015, p. 8)

O tom apodítico adotado para a criação dos enunciados (12) e (13) é o principal gatilho para o riso, pois os autores imitam as máximas científicas, pela declaração (aparente) de uma verdade insofismável. Pretendem, assim, simular a irrefutabilidade do que afirmam, ainda que a hipótese não possa ser testada no plano da realidade.

Logo, não há como assegurar que o Facebook vendeu todos os dados pessoais de alguém "para uma empresa estrangeira que fabrica panos de pratos não inflamáveis" nem que o "sinal do celular é o melhor de toda a galáxia quando você passa a 10 metros do satélite da Globastar", declarações falsas, feitas respectivamente nos enunciados (12) e (13).

A partir dos exemplos analisados, podemos dizer que a revista $M A D$, como qualquer outra com intenção de divertir, é instrumento muito necessário para a mudança de estados de ânimo. Pela prática da graça, explora o contexto social e, por meio do uso de vários raciocínios falaciosos, desperta o riso do auditório.

\section{Conclusão}

Herdamos do latim um vocábulo altamente polissêmico: graça (gratia, ae), que se liga intimamente ao ato de seduzir, de encantar, de explorar um dom natural para movimentar os humores por meio da constituição do ethos do orador. $M A D$ sabe fazer graça pela capacidade de explorar os recursos da inventio, de exercitar o uso dos lugares comuns da retórica e pela competência ao exercitar a noção do limite de aceitabilidade do auditório. MAD sabe, também, provocar o risível por meio da exploração do movimento das paixões do auditório e pela subversão bem-humorada dos fatos sociais. Vale-se, para isso, de muitos recursos tanto linguísticos quanto semânticos.

Ao explorar o plano cognitivo do auditório, utiliza-se, com muito bom humor, de falácias, como é possível verificar nos exemplos mostrados na análise. $M A D$ trabalha com a curiosidade, a pressa do leitor e, assim, tem consciência de satisfazer uma característica predominante da natureza humana: a ânsia de querer saber não apenas o que acontece, mas, sobretudo por que e como acontecem os fatos do mundo. Ao captá-los no dia a dia, subverte a ordem lógica do existir. $\mathrm{E}$ justamente aí reside a reconhecida graça da revista.

Ao se pautar pelos raciocínios falaciosos, MAD subverte as formas naturais do raciocínio indutivo e dedutivo em disparates propositalmente criados para assegurar o humor que provoca riso. Desse modo, a criação de mentiras é uma característica em MAD. Mas a mentira reveste-se de raciocínios 
aparentemente lógicos, propositalmente criados como falácias muito conscientes que, em resumo, brincam com os sentidos e a razão do auditório. A falácia torna-se, portanto, um mecanismo de produzir humor.

Pelo recurso da generalização, $M A D$ elabora e exige do leitor uma série de processos mentais de natureza indutiva e dedutiva, mas, com a mesma competência, omite a premissa maior, omite a premissa menor e faz aflorar na mente do leitor apenas a conclusão de silogismo ou entimema propositalmente criado para, assim, pela ilogicidade demonstrada, fazer rir.

Se a validade da falácia enfatiza a cooperação do receptor para o sucesso do estabelecimento de acordos entre orador e auditório, para agir como agem, os oradores da $M A D$ levam a sério um conhecimento que têm sobre seu auditório: o fato de que ele ri ao ser (e saber que é intencionalmente) enganado. É como sintetiza o título deste artigo: "me engana que eu gosta".

\section{Referências}

BERGSON, Henri. O riso: ensaio sobre a significação do cômico. 2. ed. São Paulo: Martins Fontes, 2007.

BRUM, Rodrigo. Meça suas palavras na história. Seção revisionista. MAD, São Paulo, Panini, n. 83, p. 21, mai. 2015.

CARMELINO, Ana Cristina. Humor: uma abordagem retórica e argumentativa. Desenredo, Passo Fundo, v. 8, n. 2, p. 40-56, jul./dez. 2012.

CARMELINO, Ana Cristina. (Auto)depreciação: um artifício retórico na construção do discurso humorístico. In: FERREIRA, Luiz Antonio; MAGALHÃES, Ana Lúcia (Org.). A retórica do risível. São Paulo: Cristal/Grupo ERA, 2014. p.5387.

CARMELINO, Ana Cristina; GATTI, Márcio Antônio. Ethos-stéréotypé et humour: une présidente virtuelle . Repères-Dorif. 2017. (no prelo)

COPI, Irving Marmer. Falacias no formales. In: COPI, Irving Marmer. Introducción a la lógica. 4. ed., 5. reimp. Buenos Aires: Eudeba, 2014. p. 81-121.
DOWNES, Stephen. Guia das falácias. Tradução e adaptação para o português de Portugal de Júlio Sameiro e para o português do Brasil de Ibrahim Cesar. Universidade de Alberta, Canadá, s/d. Disponível em: <http://www.onegoodmove.org/fallacy/welcome.ht m>. Acesso em: 02 ago. 2016.

FERREIRA, Luiz Antonio. Aspectos da Graça e do Risível em Retórica. In: MAGALHÃES, Ana Lúcia; FERREIRA, Luiz Antonio (Orgs.). A Retórica do risível. São Paulo: Crista/Grupo ERA, 2014. p. 3952.

FREITAS, Digo. Dez motivos mais prováveis para a falta d'água em São Paulo. Seção Cantareira, $M A D$, São Paulo, Panini, n. 79, p. 35, fev. 2015.

GARCIA, Othon Moacyr. Falácias. In: GARCIA, Othon Moacyr. Comunicação em prosa moderna: aprenda a escrever, aprendendo a pensar. 22. ed. Rio de Janeiro: Editora FGV, 2002. p. 316-323.

KEIL, Kenny. Termos e condições que podem ter passado batido por você. Seção Salada Mista. $M A D$, São Paulo, Panini, n. 83, p. 8, mai. 2015.

LIARD, Louis. Lógica. São Paulo: Companhia Nacional, 1973.

MAIKO, Scott; MECOUCH, Josh. Perguntas que gostaríamos de fazer à linha direta do Peru. Seção Dia de ação e traças. MAD, São Paulo, Panini, n. 80 , p. 40 , mar. 2015

MARCUSCHI, Luiz Antonio. Análise da Conversação. São Paulo: Ática, 1986.

OLIVEIRA, Jackson; MARTINS, José Luiz. Dicas MAD para tomar banho em tempos de falta d'água. Seção Sabão. MAD, n. 79, p. 27, fev. 2015.

POSSENTI, Sírio. Humor, língua e discurso. São Paulo: Contexto, 2010.

REÑÓN, Luis Vega. La fauna de las falacias. Madri: Trotta, 2013.

SAMPAIO, Wesley. Você sabe que gosta de apanhar quando... Seção Tapinha não dói. $M A D$, São Paulo, Panini, n. 80, p. 39, mar. 2015

SANTIBÁÑEZ YÁÑEZ, Cristián; MARAFIOTI, Roberto. Falacia, um término esquivo y vital. In: SANTIBÁÑEZ YÁÑEZ, Cristián; MARAFIOTI, Roberto. De las falacias: argumentación y comunicación. Buenos Aires: Biblos, 2008. p. 916.

SANTOPADRE, Frank; WAITE, Evan. Fatos sobre o Facebook. Sessão Zuckerbrega, MAD, São Paulo, Panini, n. 79, p. 29, fev. 2015. 


\section{COMO CITAR ESSE ARTIGO}

CARMELINO, Ana Cristina; FERREIRA, Luiz Antonio. Me engana que eu gosto! Falácias como mecanismo de produção do riso. Signo, Santa Cruz do Sul, v. 42, n. 73, jan. 2017. ISSN 1982-2014. Disponível em: <https://online.unisc.br/seer/index.php/signo/article/view/7998>. Acesso em: doi: http://dx.doi.org/10.17058/signo.v42i73.7998. 